Historic, archived document

Do not assume content reflects current scientific knowledge, policies, or practices. 



\section{Check List and Order Blank}

\section{TOWSON \\ SELECTED \\ ROSES}

T HIS list comprises some of the finest of the new roses, together with the standard and well tried varieties. Our roses are strong, field grown, budded plants, established in pots, so that they can be moved to your garden without loss, at any time after the planting season opens. We are prepared to supply the varieties described in this list in any quantity. Order now for full and continuous blooming season.

\section{As all plants are subject to prior sale, for complete selection, order immediately}

\section{HYBRID TEA ROSES}

Autumn-Burnt orange, streaked and marked with red. Double fragrant, attractive flower.

$\$ 1.00$

Better Times-A new outstanding rose with long crimson buds opening into large, double, brilliant cerise-red flowers

$\$ 1.50$

Betty Uprichard-Inner face of petal delicate salmon pink, outside glowing carmine with copper sheen. Strong grower $\$ .85$

Caledonia-Very large pointed buds. Color at first slightly yellow, changing to pure white ___ $\$ .85$

Crimson Glory-Large, urn-shaped buds opening to well formed flowers of an intense deep crimson, shaded oxblood red and mellowed by a soft velvety nap__ $\$ 1.50$

Dame Edith Helen-Brilliant, yet soft, pink. Perfect buds developing into wonderful flowers on long, strong stems__ $\$ .85$

Duchess of Atholl-Unique, golden orange, flushed with peach pink. Vigorous, profuse bloomer

$\$ 1.00$

Duchess of Wellington-Yellow. Extra long pointed buds of golden orange which open to beautiful saffron flowers-very fragrant _._ $\$ .85$

Edel-Large, stately blooms of pure ivory white. Very vigorous ___ $\$ .85$

Edith Nellie Perkins-A rose of outstanding merit. Vigorous in growth and free flowering. Outside of petals orient-red shaded cerise-orange, inside salmon pink $\$ \mathbf{8 5}$

E. G. Hill-Long buds, full double flowers. Dazzling red, shading to darker crimson.

$\$ .75$

Etoile de Hollande-Crimson red. Very fragrant, particularly free flowering and healthy

$\$ .75$

Golden Dawn-The ideal yellow rose, large, double sweetly scented flowers. Vigorous and free flowering.

$\$ 1.00$

Joanna Hill-Splendid clear yellow. Pointed buds opening to semi-double, long-lasting, moderately fragrant flowers
Lady Alice Stanley-Large cup-shaped flowers-deep rose on outside-flesh pink inside. Very fragrant. Double flowers $\$ .85$

Lady Fortevoit-Several large blooms on long stems. Golden yellow changing to deep apricot $\$ .85$

Little Beauty-New everblooming rose of brilliant cerise, passing to soft deep pink

$\$ 1.50$

Margaret McGredy-Large, double flowers of an entrancing shade of rich oriental red, passing to carmine rose

$\$ .85$

McGredy's Scarlet - Strong, vigorous growth, free flowering and brilliant color, double, brilliant scarlet, orange-yellow at base of petals__ $\$ .75$

Mevrouw G. A. Van Rossem-Unusual coloring. Vivid orange and apricot on a golden yellow ground

$\$ 1.00$

Mme. Edouard Herriot-Buds of Coral red, and orange, opening to an indescribable orange red and salmon

Miss Rowena Thom-Long and shapely buds, opening to large, perfect double flowers of brilliant pink

$\$ .85$

Mrs. E. P. Thom-Rich deep lemon yellow, sweetly scented

$\$ .75$

Mrs. Henry Bowles-Clear pink, slightly shaded with lighter salmon pink. Free flowering

$\$ .85$

Mrs. J. D. Eisele-Rose of outstanding merit with perfect buds and flowers of cherry rose $\$ 1.50$

Mons. Jules Bouche-Superb white flowers shaded light blush in center, fully double, fragrant _ $\$ .75$

Nigrette-Deep maroon resembling blackvelvet. Medium sized flowers with a slight fragrance

$\$ 2.00$

President Hoover-Splendid combination of cerise pink, flame, scarlet and yellow. Exquisitely perfumed

Radiance-Light pink, very fragrant, prolific bloomer. The most reliable hybrid tea rose 
Red Radiance-A light crimson red variation of Radiance. Dependable bloomer; excellent foliage

$\$ .75$

Rev. F. Page Roberts-A glorious Rosecopper-red buds of great length opening to golden yellow blooms stained outside with red

$\$ .85$

Sou. de Claudius Pernet-Brilliant yellow; inclined to dark center, rather single $\$ \mathbf{\$} .75$

Talisman-Long pointed buds of bright yellow. As petals unfold they develop into double, fragrant high centered flowers that combine bright apricot, gold and deep rose-pink

$\$ .75$

Ville de Paris (City of Paris) - Rich buttercup yellow without a trace of other color. Always retains its richness

$\$ 1.00$

Wilhelm Kordes-Unique rich red coppery suffusion overlaying a golden salmon ground. Very fragrant

$\$ .85$

Roses priced at $\$ .85$ each $-\$ 9.00$ per dozen Roses priced at $\$ .75$ each- $\$ 8.00$ per dozen

\section{POLYANTHA OR BABY ROSES}

Magnifique-Splendid large flowers of clear shell pink borne in large trusses. Blooms profusely

$\$ .85$

Lafayette-Very atractive, large bright crimson-scarlet in sprays of 40 or more flowers each. Can be depended upon for a continuous display throughout the season

\section{$\$ .85$ each- $\$ 9.00$ per dozen}

Roulette-A midget rose, less than 6 " high, tiny flowers, pale pink and produced all season

$\$ .50$

\section{HARDY CLIMBING ROSES}

Albertine-Large, semi-double, peach-colored flowers produced in reckless profusion $\$ .75$

American Pillar-Enormous clusters of single, brilliant pink flowers with white and gold centers, extremely vigorous___ $\$ .75$

Blaze-New, hardy vigorous, climber with blazing color of Paul's Scarlet, and everblooming habit of the Gruss en Teplitz. Patented $\$ 1.50$

Chaplins Pink-A rich, lively pink, color retained from bud to flowers.

$\$ .75$

Christine Wright-Large, cup-shaped flowers of wild rose pink color. Long stemmed sprays
Climbing American Beauty-Large, beautiful blooms of rich red-purple, fragrant, moderate growth

Climbing Betty-Coppery pink buds of exquisite form, opening to large, rather loosely formed, pale buff-pink flowers. Very long stems, excellent bloomer

$\$ 1.50$

Dr. Van Fleet-Large, exquisite, pale pink flowers on long stems for cutting, strong grower

$\$ .75$

Emily Gray-Large, semi-double, rich buff yellow flowers; scented. Bronzy foliage

$\$ .75$

Golden Climber (Mrs. A. C. James). True golden yellow climber with quality blooms. Petals gracefully ruffled $\$ \mathbf{\$ 2 . 0 0}$

Jacotte-Large, semi-double bronze yellow and apricot flowers. Very lasting__ \$.75

Lady Ashtown-Long buds of clear pink. The best of the Hybrid tea climbers_\$1.25

Mme. Edouard Herriot-Buds of coral red and orange-opening to orange red and salmon

$\$ 1.25$

Mme. Gregoire Staechelin-Crimson in bud, opening to pearl pink splashed with carmine

$\$ 1.00$

Mrs. Arthur Curtis James-See "Golden Climber"

$\$ 2.00$

Mary Wallace-Large, luminous pink flowers on long stems, handsome and very popular

New Dawn (Everblooming Dr. Van Fleet) -Blooms continuously throughout the summer. Patented $\$ 1.50$

Paul's Scarlet-Large, well shaped flowers of brilliant blazing scarlet. Brightest red of all climbers

$\$ .75$

Sky Rocket-Beautiful new everblooming pillar rose, with large clusters of medium sized, brilliant rich red blooms.

$\$ 1.50$

Silver Moon-Enormous, almost single, pure white flowers with golden yellow centers

$\$ .75$

Roses priced at $\$ .75$ each $-\$ 8.00$ per dozen

\section{SPECIES}

Rosa Hugonis-A splendid Rose for the shrubbery border. Delicate, single yellow flowers on long, arching sprays early in May $\$ .85$ each $-\$ 9.00$ per dozen

\section{TOWSON NURSERIES, INC. - TOWSON, MARYLAND}

NAME ADDRESS 


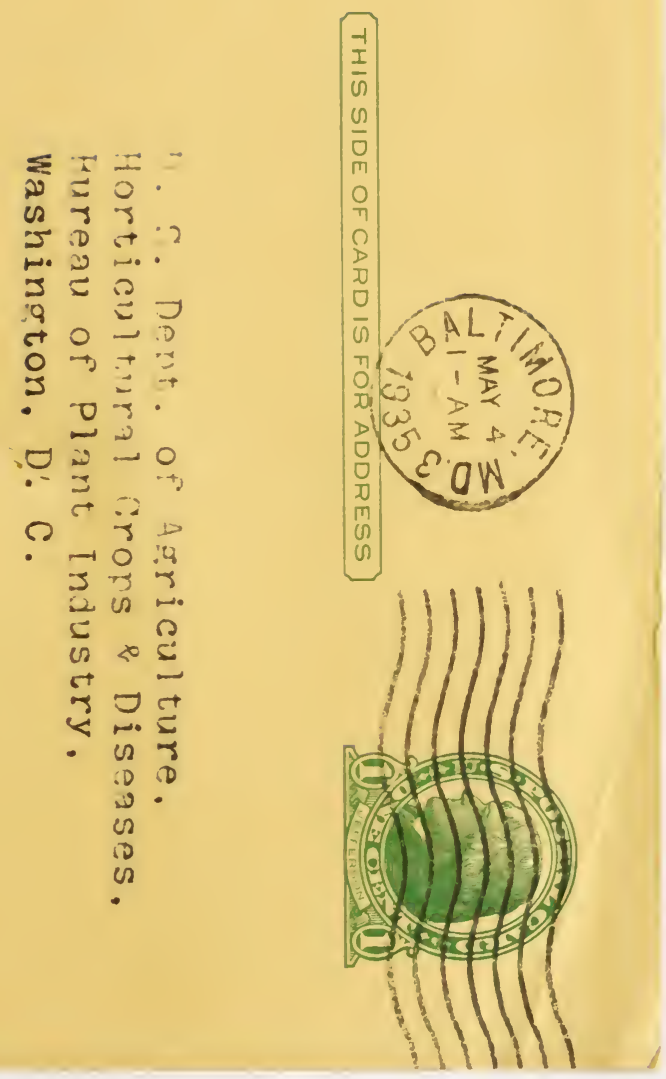


Come to Towson

\section{At Azatea Time}

Join the thousands who renew their acquaintance each year with European and Oriental Azaleas in all the splendor of their magnificent colorings.

IN FULL BLOOM FROM MAY 4th TO MAY 18th One of the outstanding flower shows of the country. Special showings each week day. Added features each week-end. Visitors welcome. Ample parking. No admission charge.

\section{TOWSON NURSERIES, INC. TOWSON - MARYLAND}

York Road opposite Maryland State Normal School $1 / 2$ Mile from Towson . . . 7 Miles from Baltimore
NEW AZALEAS

shown commercially

for the first time

IN AMERICA

Several years ago the U. S. Dept. of Agricul ture imported from Japan a number of new varieties of hardy evergreen Azaleas. From these the most outstanding were selected. Tow. son Nurseries was selected as one of the lected as one of the original growers to propogate them. All are sinof flower, foliage, and habit of growth, and most of them bloom after the well known variethe well known varieties such as Azalea amoena and Azalea hinodegiri. have finished blooming. These are rare a n d outstanding feature of Towson's Azalea Exhibition. They prolong the blooming prolong the blooming season of the Azalea family and add exquisite 